\title{
Functional and Phenotypic Studies of Japanese Adult T Cell Leukemia Cells
}

\author{
Chikao Morimoto, Takami Matsuyama, Chikara Oshige, Hiromitsu Tanaka, Thierry Hercend, \\ Ellis L. Reinherz, and Stuart F. Schlossman \\ Division of Tumor Immunology, Dana-Farber Cancer Institute, Department of Medicine, Harvard Medical School, Boston, \\ Massachusetts 02115; The First Department of Internal Medicine, Kagoshima University School of Medicine, Kagoshima, Japan
}

\section{Abstract}

The cell surface marker profile and functional analysis of peripheral blood lymphocytes from 11 Japanese adult $\mathbf{T}$ cell leukemia patients were studied.

The phenotypic analysis of Japanese adult $\mathbf{T}$ cell leukemia (ATL) cells by a series of 13 monoclonal antibodies showed that all ATL cells are anti-T4 reactive but some differ in their expression of T3, T11, and T12 antigens. Thus, considerable phenotypic heterogeneity exists in these populations of leukemia cells. When analyzed in functional assays, ATL cells were suppressive when added to a pokeweed mitogen- (PWM) driven Ig synthesis system. However, the suppression mechanism seemed to be more complex than originally conceived. ATL cells examined in this study seem to function mainly as an inducer of suppressor cells, and as such, activate normal T8 precursors of suppressor cells rather than function as suppressor effector cells. In addition, no evidence was obtained to suggest that suppression of PWM-stimulated IgG synthesis was mediated by natural killer (NK) activity of ATL cells. Rather, ATL cells seem to be markedly deficient in NK activity.

These studies suggest that the majority of ATL cells tested are representative of and seem to be the leukemic counterparts of the T4+ suppressor inducer subset.

\section{Introduction}

Numerous studies have shown that $T$ cell subsets are involved in a complex series of interactions that regulate the immune response $(1,2)$. Multiple cell-cell interactions have been shown to be necessary to translate an antigenic signal into both an effective immune response and its homeostatic controls.

The use of specific anti-T cell monoclonal antibodies has facilitated the analysis of human $T$ cells and their division into distinct subpopulations of cells based on the expression of cell surface antigens (3-6). Perhaps of greatest interest was the demonstration that communicative interactions occurred both between and within the major populations of cells in the generation of specific effector functions. For example, interactions between a subpopulation of $\mathrm{T} 4$ and $\mathrm{T} 8$ cells are required to induce suppression of $\mathrm{Ig}$ production in antigen

Address reprint requests to Dr. Morimoto, Division of Tumor Immunology, Dana-Farber Cancer Institute, Boston, MA 02115.

Received for publication 3 May 1984 and in revised form 5 November 1984.

\section{J. Clin. Invest.}

(c) The American Society for Clinical Investigation, Inc.

0021-9738/85/03/836/08 $\$ 1.00$

Volume 75, March 1985, 836-843 specific, pokeweed mitogen (PWM) ${ }^{1}$ driven and autologous mixed leukocyte reaction systems (7-10). The human immunoregulatory circuit is clearly composed of discrete subsets of still poorly defined cells that interact to maintain homeostasis $(10,11)$.

It has been long regarded that human leukemic $\mathrm{T}$ cells with mature $T$ cell surface phenotypes may represent the clonal expansion of a subset(s) of cell with distinct immunoregulatory programs. Functional and phenotypic analysis of such cells can provide valuable insights into the function of normal $T$ cells. Japanese adult $T$ cell leukemia (ATL) is a unique $\mathrm{T}$ cell leukemia with clinical features including visceral and skin infiltrations by leukemic cells, a subacute or chronic clinical course, and the clustering of patients' birth places (12, 13). Recently, a unique human type $C$ retrovirus, human $T$ cell leukemia/lymphoma virus (HTLV), has been isolated from the neoplastic $\mathrm{T}$ cells of patients with ATL in multiple areas of the world (14-16), and data suggest that ATL is causally related to infection with ATLV/HTLV. Phenotypically, most ATL cells have been shown to possess the helper/inducer phenotype, i.e., T4 positive, despite the clear finding that cells from many of these patients suppress PWM-induced normal B cell differentiation (17-19). In contrast, T4 positive leukemic cells from patients with Sezary syndrome often functioned as helper cells in the same PWM assay systems (20, 21).

The precise cellular mechanism by which ATL cells suppress PWM induced normal B cell differentiation is still not clear. In this study, we examined both the cell surface phenotype and the immunoregulatory effects of leukemic cells from 11 Japanese patients with the clinical diagnosis of ATL. The results shown below indicate that while most ATL cells are T4+, considerable phenotypic heterogeneity exists when these cells are analyzed with a series of anti-T cell antibodies. Perhaps most importantly, these ATL cells seemed to correspond functionally to the T4+ inducer of the T8+ suppressor population rather than to a suppressor effector population.

\section{Methods}

Subjects. 11 patients with typical ATL who were admitted to the Kagoshima University Hospital, Kagoshima, Japan were selected for this study. Diagnosis was made by clinical and hematologic findings proposed by Takatsuki et al. $(12,13)$. The patients whose ATL cells in peripheral blood were lower than $10 \%$ were excluded. Six healthy normal volunteer donors were also used for functional studies of ATL cells.

Isolation of lymphoid populations. Human peripheral blood mononuclear cells were isolated from healthy volunteer donors or patients

1. Abbreviations used in this paper: ATL, adult T cell leukemia; C, human complement; HTLV, human T cell leukemia/lymphoma virus; IL-1, interleukin 1; IL-2, interleukin 2; PBL, peripheral blood lymphocytes; PWM, pokeweed mitogen. 
with ATL by Ficoll-Hypaque density gradient centrifugation (Pharmacia Fine Chemicals, Piscataway, NJ). Unfractionated mononuclear cells were first depleted of macrophages by adherence to plastic as previously described (22). The adherent cells were recovered and used as a macrophage enriched population. The macrophage-depleted mononuclear cells were separated into E-rosette positive $(\mathrm{E}+)$ and E-rosette negative (E-) populations with $5 \%$ sheep erythrocytes (M. A. Bioproducts, Bethesda, MD). The rosetted mixture was layered over FicollHypaque and the recovered E+ pellet was treated with $0.155 \mathrm{M} \mathrm{NH}_{4} \mathrm{Cl}$ to lyse erythrocytes. The $\mathrm{T}$ cell population thus obtained was $>95 \%$ $\mathrm{E}+$ and $>94 \%$ reactive with monoclonal antibody anti-T3, which defines an antigen present on all mature peripheral $\mathrm{T}$ lymphocytes (23). The E- population was highly enriched for B cells by complement (C)-mediated lysis with anti-monocyte antibody, anti-Mol antibody (24). This rationale was used since it was previously shown that Epopulations contained many null cells that are reactive with anti-Mol antibody. To eliminate contaminated $T$ cells from $E-$ populations, this E- population was further treated with anti-T3 antibody and C. Reanalysis of these antibodies lysed subpopulations of E- cells (B cells) demonstrated $<5 \%$ anti-Mol and anti-T3 reactive cells and $>90 \%$ of cells were reactive with anti-Bl monoclonal antibody, which defines an antigen present on all peripheral B cells (28). Isolated leukemic cells were studied either fresh or cryopreserved in $10 \%$ dimethylsulfoxide and $20 \%$ fetal calf serum at $-196^{\circ} \mathrm{C}$ in the vapor phase of liquid nitrogen until the time of characterization.

Production of monoclonal antibodies and cell sorter analysis. A series of monoclonal antibodies was used to define the cell surface antigens on adult $T$ cell leukemic cells. The production and characterization of monoclonal antibodies, including anti-T3, T4, T8, T6, T9, $\mathrm{T} 10, \mathrm{~T} 11, \mathrm{~T} 12, \mathrm{~B} 1, \mathrm{~J} 5$, and Ia, used in these studies have been previously described in detail (23-30) and are available through Coulter Electronics, Inc., Hialeah, FL. Anti-Tac monoclonal antibody (generously provided by Dr. T. A. Waldman, National Cancer Institute, Bethesda, MD) reacts with activated $T$ cells and is known to react with interleuken 2 (IL-2) receptor $(6,31)$. The 901 antigen is expressed on $7 \%$ peripheral blood mononuclear cells and morphologically seems to be large granular lymphocytes. $>95 \%$ of natural killer (NK) activity in peripheral blood is found within the purified $901+$ fraction (32). Anti-901 antibody was found to be reactive with $1 \%$ of $\mathrm{T} 3+$ cells by fluorescence microscopy, but does not react with monocytes, granulocytes, B cells, erythrocytes, or platelets. Cytofluorographic analysis of cell populations was performed by indirect immunofluorescence with fluorescein-conjugated goat anti-mouse IgG on a fluorescence-activated cell sorter as previously described (33). Background fluorescence reactivity was determined with a control ascites obtained from mice immunized with nonsecreting hybridoma clones.

Complement-dependent lysis of lymphocytes with monoclonal antibodies. E+ lymphocytes were treated with anti-T4 or anti-T8 monoclonal antibodies and rabbit C (Pel-Freeze Biologicals, Rogers, AR). These antibodies of the IgG2 subclass have been described elsewhere $(27,34)$. Briefly, $2 \times 10^{7}$ cell aliquots were incubated with $1 \mathrm{ml}$ of antibody at a 1:250 dilution for $1 \mathrm{~h}$ at room temperature and then 0.3 $\mathrm{ml}$ rabbit $\mathrm{C}$ was added to the mixture. The mixture was incubated for another hour in a $37^{\circ} \mathrm{C}$ shaking water bath, washed, and these procedures were repeated twice. After lysis of cells with anti-T4 and C, $>90 \%$ of the residual cells were T $8+$ cells, whereas $<5 \%$ were T4+ cells; after lysis with anti-T8 and C, $>90 \%$ of the remaining cells were T4+ cells and $<5 \%$ were T8+ cells. These two populations will be referred to as $\mathrm{T} 8+$ and $\mathrm{T} 4+$ subsets, respectively.

Help and suppression of in vitro IgG secretion. Helper, suppressor inducer activity, and suppressor effector activity of healthy donor T4+ and T8+ cells and patient cells were evaluated on PWM-driven IgG synthesis as described previously $(8,11)$.

Unfractionated and separated populations of lymphocytes were cultured in round-bottomed microtiter culture plates (Falcon, Div. Becton-Dickinson \& Co., Oxnard, CA) at $37^{\circ} \mathrm{C}$ in a humid atmosphere with $5 \% \mathrm{CO}_{2}$ for $7 \mathrm{~d}$ in RPMI 1640 supplemented with $20 \%$ heatinactivated fetal calf serum (Microbiological Associates), $0.5 \%$ sodium bicarbonate, $200 \mathrm{mM}$ L-glutamine, $25 \mathrm{mM}$ Hepes, and $1 \%$ penicillinstreptomycin. To determine the helper activity of patients' cells, various numbers of the cells were added to $5 \times 10^{4}$ healthy donor $B$ cells in a volume of $0.1 \mathrm{ml}$. As a control, various numbers of the healthy donor T4 cells were added to $5 \times 10^{4}$ healthy donor B cells. To this was added $0.1 \mathrm{ml}$ of PWM (Gibco Laboratories, Grand Island, NY) at a 1:50 dilution. Macrophages were added to all populations at a 5\% final concentration at the initiation of in vitro cultures. To assess the possible regulatory effect of patients' cells on PWM-driven IgG secretion, varying numbers of patients' cells were added to a mixture of $2 \times 10^{4}$ normal T4 and $5 \times 10^{4} \mathrm{~B}$ cells in the presence or absence of $1 \times 10^{4}$ normal T8 cells with PWM. In some experiments, patients' cells or normal T4 subsets were irradiated with 1,500 rad by using a gamma cell 40 (Atomic Energy of Canada Ltd., Ottawa, Ontario, Canada) irradiation source as described previously (9). On day 7 , cultures were terminated, supernatants were harvested, and IgG secretion into supernatant was determined by solid phase radioimmunoassay (RIA) using a monoclonal antibody directed at the Fc portion of the human gamma heavy chain (anti- $\gamma \mathrm{Fc}$ ) (gifted by Dr. Vic Raso, DanaFarber Cancer Institute) as previously described $(8,11)$.

Cytotoxicity assay. To assess NK activity of patients' cells, 2,500$5,000{ }^{51} \mathrm{Cr}$-labeled target cells (J. M. T cell lines) were incubated with various numbers of effector cells at $37^{\circ} \mathrm{C}$ in V-bottom microtiter plates. Subsequently, plates were spun and cytotoxicity was measured by the release of ${ }^{51} \mathrm{Cr}$ into the supernatant after a 4-h incubation. The maximal release was determined by addition of $1 \%$ nonidet $\mathrm{P}-40$ detergent. Spontaneous release never exceeded $20 \%$, and the specific cytotoxicity was calculated as described previously (35). As a control, human NK clone (J-T9) was used and its characteristics were described elsewhere (36). Medium for cytotoxic assays was RPMI 1640 plus $20 \%$ human $\mathrm{AB}$ pooled serum and $1 \%$ penicillin-streptomycin.

Determination of anti-ATLV antibody. Anti-ATLV antibody titer was determined by an indirect-immunofluorescence test using MT-1 cells as previously described (16).

\section{Results}

Cell surface phenotype of peripheral blood lymphocyte (PBL) from patients with Japanese ATL. The clinical and laboratory features of the 11 patients with ATL are listed in Table $\mathbf{I}$. There were seven male and four female patients with an age range of 34-81 yr. All the patients were born in southern parts of Kyushu in Japan. Eight patients showed skin eruptions (generalized erythroderma, disseminated milliary erythema, or cutaneous nodules). Nine patients had mild to moderate lymph node enlargement and hypercalcemia was observed in only two patients. Serum immunoglobulin levels were studied in 7 of the 11 patients with ATL, and these values were within normal limits. Anti-ATLV antibody titer of the serum was studied in seven of the patients by using an indirect immunofluorescence method, and all seven patients tested were positive.

The cell surface marker profiles of PBL from all patients tested showed that their ATL cells were T4+T6-T8-B1-J5-. Other antigens such as T3, T11, and T12, shown to be present on all normal mature $T$ cells, were not invariably found on ATL cells but at times were anomalously expressed (patients 4, 6, 8, and 10). Although most ATL cells have the mature normal $\mathrm{T}$ inducer phenotype, that is, $\mathrm{T} 3+\mathrm{T} 4+\mathrm{T} 11+\mathrm{T} 12+$, some ATL cells lacked reactivity with $\mathrm{T} 3, \mathrm{~T} 11$, and $\mathrm{T} 12$. The reactivity with anti-T9, T10, and Ia was also variable but expected since expression of these antigens are frequently dependent on the state of activation of the cell. Moreover, there was no consistent pattern or correlation of activation antigen expression. Ia, T9, T10, and Tac antigens are invariably 


\begin{tabular}{|c|c|c|c|c|c|c|c|c|c|c|c|c|}
\hline \multirow[b]{2}{*}{$\begin{array}{l}\text { Patient } \\
\text { no. }\end{array}$} & \multirow[b]{2}{*}{ Age } & \multirow[b]{2}{*}{ Sex } & \multirow[b]{2}{*}{ Survival } & \multirow[b]{2}{*}{ Onset of disease } & \multirow[b]{2}{*}{$\begin{array}{l}\text { Lymphad- } \\
\text { enopathy }\end{array}$} & \multirow[b]{2}{*}{$\begin{array}{l}\text { Skin } \\
\text { lesion }\end{array}$} & \multirow[b]{2}{*}{$\begin{array}{l}\text { Hyper- } \\
\text { calcemia }\end{array}$} & \multirow[b]{2}{*}{$\begin{array}{l}\text { Lympho- } \\
\text { cytes }\end{array}$} & \multirow[b]{2}{*}{$\alpha \mathrm{ATLV}$} & \multicolumn{3}{|c|}{ Normal range } \\
\hline & & & & & & & & & & $\begin{array}{l}\text { IgG } \\
570-1,780\end{array}$ & $\begin{array}{l}\text { IgM } \\
54-380\end{array}$ & $\begin{array}{l}\text { IgA } \\
85-385\end{array}$ \\
\hline & $y r$ & & mo & & & & & & & & & \\
\hline 1 & 49 & $F$ & 6 & Skin eruption & + & + & - & 11,200 & N.D.* & N.D. & N.D. & N.D. \\
\hline 2 & 52 & $\mathbf{M}$ & 18 & Fever, general fatigue & + & + & + & 31,000 & N.D. & 1,562 & 215 & 124 \\
\hline 3 & 66 & $\mathbf{M}$ & 9 & $\begin{array}{l}\text { Lymph node } \\
\text { enlargement }\end{array}$ & + & + & - & 10,700 & $40 \mathrm{X}$ & 1,776 & 408 & 70 \\
\hline 4 & 56 & $\mathbf{M}$ & 21 & Skin eruption, fever & - & + & - & 40,900 & $10 \mathrm{X}$ & 1,020 & 162 & 208 \\
\hline 5 & 72 & $\mathbf{M}$ & 2 & Unconsciousness, fever & + & + & + & 45,000 & $10 \mathrm{X}$ & 758 & 66 & 116 \\
\hline 6 & 81 & $\mathrm{~F}$ & 1 & General fatigue & + & + & - & 34,000 & N.D. & N.D. & N.D. & N.D. \\
\hline 7 & 64 & $\mathbf{F}$ & 9 & $\begin{array}{l}\text { Lymph node } \\
\text { enlargement }\end{array}$ & + & - & - & 9,200 & $80 \mathrm{X}$ & 2,383 & 264 & 259 \\
\hline 8 & 71 & $\mathbf{M}$ & 76 & Skin eruption, itching & + & + & - & 10,200 & $40 X$ & 1,662 & 304 & 288 \\
\hline 9 & 55 & $\mathbf{M}$ & 4 & General fatigue & + & - & - & 45,000 & $320 \mathrm{X}$ & 1,563 & 82 & 265 \\
\hline 10 & 34 & $\mathbf{M}$ & 6 & Skin eruption, itching & + & + & - & 22,500 & N.D. & N.D. & N.D. & N.D. \\
\hline 11 & 51 & $\mathrm{~F}$ & 24 & Fever paraplegia, cough & - & - & - & 9,900 & $100 \mathrm{X}$ & N.D. & N.D. & N.D. \\
\hline
\end{tabular}

* N.D., not done.

present on normal activated $T$ cells, but in these studies variable expression of these antigens was observed and only one of seven patients' cells tested was strongly Tac reactive. In addition, cells from all the patients were unreactive with anti-901, an antibody known to define NK cells. These phenotypic results indicate that while $\mathrm{T} 4$ is most often expressed, considerable heterogeneity exists.

$P W M$-stimulated IgG synthesis by normal B cells cocultured with irradiated or nonirradiated ATL cells. Since all ATL cells belonged to T4+ subset, we examined the capacity of ATL cells to provide help in a PWM stimulated B cell immunoglobulin production system. For this purpose, varying numbers of ATL cells or normal T4 cells were mixed with normal allogeneic B lymphocytes and stimulated with PWM in vitro. At the end of $7 \mathrm{~d}$ in culture, total IgG production was measured by RIA.

As shown in Fig. 1, when varying numbers of normal T4

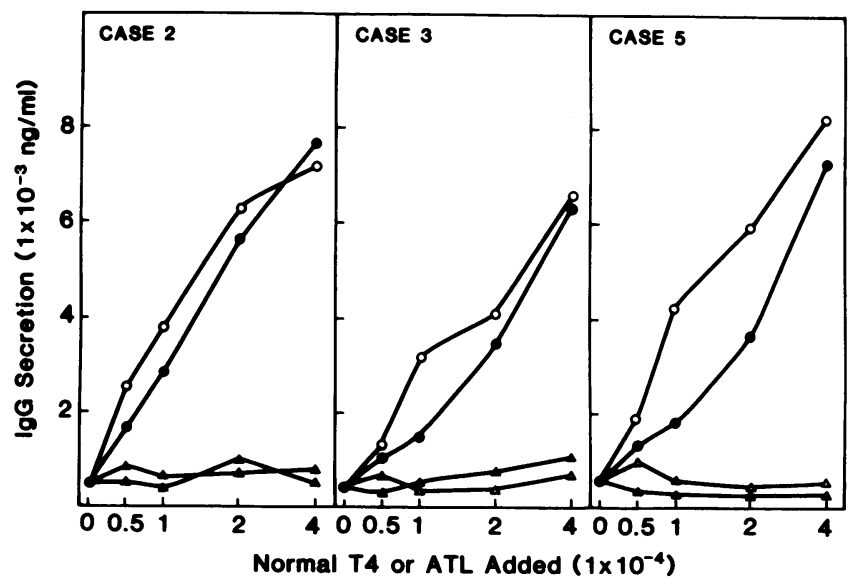

Figure 1. PWM-stimulated IgG synthesis by normal B cells cocultured with irradiated or nonirradiated ATL cells and normal T4 cells. Varying numbers of nonirradiated (-O - ) and irradiated (- $\bullet-)$ normal T4 cells or nonirradiated $(-\Delta-)$ and irradiated $(-\Delta-)$ ATL cells were mixed with allogeneic B lymphocytes $\left(5 \times 10^{4}\right)$ and stimulated with PWM in vitro for $7 \mathrm{~d}$. Supernatants were analyzed for IgG in a solid phase RIA. Results are mean of triplicate samples. SE was $<10 \%$. cells were mixed with allogeneic B cells with PWM, increasing amounts of IgG production were observed in a dose-dependent manner. In contrast, when varying numbers of ATL cells were mixed with allogeneic B cells and PWM, no enhanced immunoglobulin production was observed. Moreover, irradiation of the ATL cells with the view of diminishing suppressor activity failed to enhance immunoglobulin production. In this regard, a number of laboratories has shown that the suppressor activity of cells is relatively radiosensitive, whereas helper activity seems to be relatively radioresistant $(7,9)$. While no effect was seen with ATL cells, when normal T4 cells were irradiated, the effect of suboptimal numbers of irradiated T4 cells in providing help was less than the effect of unirradiated T4 cells (Fig. 1). In contrast, when supraoptimal numbers of irradiated T4 cells were used, there was a little difference between the amount of help provided by either irradiated or unirradiated $\mathrm{T} 4+$ cells.

Immunoregulatory function of ATL cells on PWM stimulated IgG production. Regulatory influence of ATL cells (cases 3, 5, and 9) on PWM stimulated IgG production was next examined. As shown in Fig. 2, when increasing numbers of ATL cells were cultured with normal PBL with PWM, a cell dependent increase in suppression of PWM stimulated IgG production was observed. However, when irradiated ATL cells were cultured with normal PBL, no suppression of PWM stimulated IgG production was observed. Comparable suppression by ATL cells was also observed in three additional patients tested (cases 2, 4, 10) (Table I). These results are similar to that previously described, which indicated that Japanese ATL cells lacked helper activity but demonstrated suppressor activity (17, 18).

Cellular basis of suppression of PWM stimulated IgG synthesis by Japanese ATL cells. In earlier studies employing heterogeneous peripheral blood $T$ cell populations, it was demonstrated that the generation of suppression required an interaction between a radiosensitive $\mathrm{T} 4+$ inducer cell and a radiosensitive $\mathrm{T} 8+$ suppressor cell $(7,9)$. The former was necessary to activate the latter to become a $\mathrm{T} 8+$ suppressor effector cell. It was, therefore, important to determine whether Japanese ATL cells were themselves capable of directly suppressing IgG synthesis, or alternatively, whether or not they 


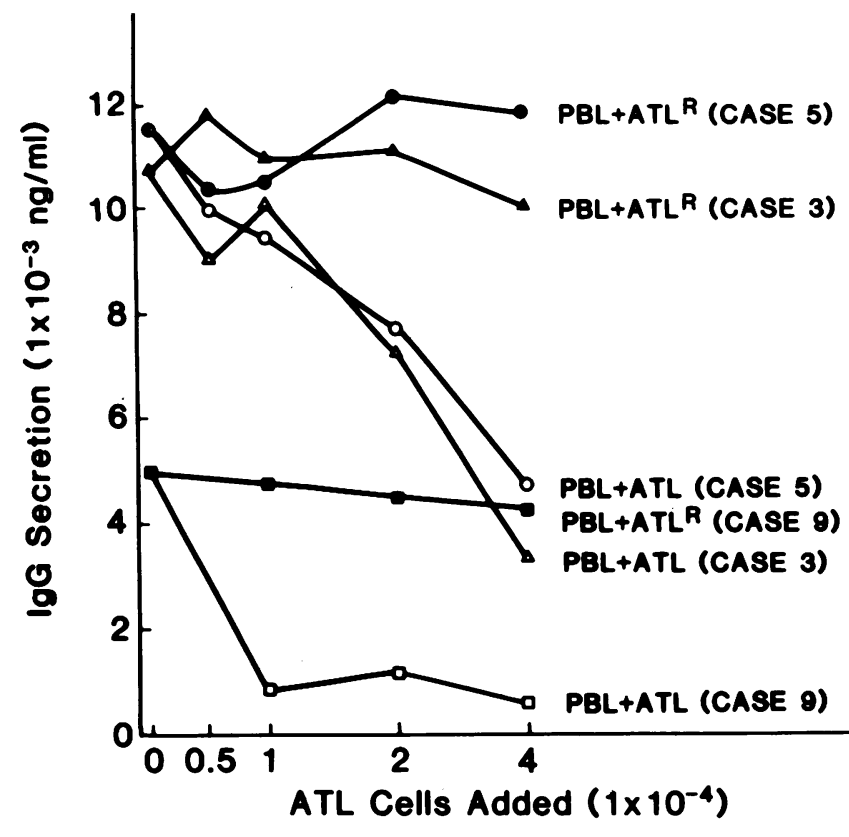

Figure 2. Immunoregulatory function of ATL cells on PWM stimulated IgG production. Varying numbers of ATL cells (cases 3, 5,9) were cultured with normal PBL $\left(1 \times 10^{5}\right)$ in the presence of PWM for $7 \mathrm{~d}$. Supernatants were analyzed for IgG in a solid phase RIA. ATL cells were irradiated $(1,500 \mathrm{rad})$. Results are mean of triplicate samples. SE was $<10 \%$.

mediated suppression through an additional $\mathrm{T}$ cell population. To this end, varying numbers of ATL cells were added to a mixture of B cells $\left(5 \times 10^{4}\right)$ and T4 cells $\left(2 \times 10^{4}\right)$ in the presence or absence of T8 cells $\left(1 \times 10^{4}\right)$. The mixture was stimulated with PWM for $7 \mathrm{~d}$ and IgG synthesis was assayed in a solid phase RIA. As shown in Fig. 3, for example, the mixture of PWM stimulated normal B cells and T4+ cells resulted in 7,200 ng/ml of $\mathrm{IgG}$ during 7-d culture supernatant. Addition of ATL cells from patient 2 to this T4+ plus B cell mixture did not result in suppression of IgG production. Similar results were obtained with ATL cells from patients 3, 5 , and 9 . The above findings suggest that the suppressive effect of ATL cells was not direct but perhaps mediated via $\mathrm{T} 8+$ cells present in the culture. To test this possibility, ATL cells were added to a mixture of B cells, T4+ cells, and T8+ cells stimulated by PWM. As shown in Fig. 3, the mixture of PWM stimulated normal B cells, T4+ cells, and T8 cells resulted in $2,800 \mathrm{ng} / \mathrm{ml}$ of $\mathrm{IgG}$, which was less than that obtained with B and T4 cells alone (see Case 2 panel). More importantly, the addition of ATL cells from case 2 to this mixture resulted in marked suppression of IgG production $(600 \mathrm{ng} / \mathrm{ml})$. Similar results were obtained in three other ATL cells (cases 3, 5, and 9). These results imply that the ATL cells themselves have little direct suppressive effects on IgG production, but rather induce or activate T8 cells to become suppressor effector cells. Note that ATL cells from cases 2, 3, and 9 were fresh cells, and ATL cells from case 5 were cryopreserved cells. In earlier studies it was shown that T4 suppressor inducer cells were sensitive to low doses of irradiation $(7,9)$. To determine whether ATL cells were radiosensitive, we undertook a number of experiments. To a mixture of B cells containing either irradiated or nonirradiated T4 or ATL cells in the presence of PWM, varying numbers of fresh normal T8 cells were added. IgG production was assayed by RIA using the 7-d culture supernatant. As shown in Fig. 4, when T8 cells were added to a mixture of B cells and T4 cells, marked suppression of IgG production was observed. However, when T8 cells were added to a mixture of B cells and irradiated T4 cells, little suppression of IgG production was observed. More importantly, addition of ATL cells to the mixture of B cells and irradiated T4 cells restored the capacity of increasing numbers of $T 8+T$ cells to effect suppression. On the other hand, when T8 cells were added to a mixture of B cells containing both irradiated T4 and ATL cells, no suppression of IgG production was observed. These results provide additional evidence for the notion that ATL cells function as a suppressor inducer rather than a suppressor effector cell, and that this functionally distinct population is radiosensitive.

NK activity of $A T L$ cells. A number of investigations have indicated that the Tac antigen (i.e., IL-2 receptor) is enhanced on ATL cells after in vitro culture $(13,17,37)$. Since the Tac antigen is strongly expressed on activated $\mathrm{T}$ cells, it was important to exclude the possibility that suppression of $\mathrm{IgG}$ production was mediated by NK activity of ATL cells, since activated $T$ cells can mediate NK activity (38). For this purpose, freshly thawed and 7-d cultured ATL cells with PWM were assayed for their NK activity.

Table II. Surface Phenotype and Function of Japanese Adult T Cell Leukemia Cells

\begin{tabular}{|c|c|c|c|c|c|c|c|c|c|c|c|c|c|c|c|}
\hline \multirow{2}{*}{$\begin{array}{l}\text { Patient } \\
\text { no. }\end{array}$} & \multirow[b]{2}{*}{ T3 } & \multirow[b]{2}{*}{ T4 } & \multirow[b]{2}{*}{ T6 } & \multirow[b]{2}{*}{ T8 } & \multirow[b]{2}{*}{ T9 } & \multirow[b]{2}{*}{ T10 } & \multirow[b]{2}{*}{$\mathrm{T} 11$} & \multirow[b]{2}{*}{$\mathrm{T} 12$} & \multirow[b]{2}{*}{ B1 } & \multirow[b]{2}{*}{ J5 } & \multirow[b]{2}{*}{ Ia } & \multirow[b]{2}{*}{ TAC } & \multirow[b]{2}{*}{901} & \multicolumn{2}{|l|}{ Function } \\
\hline & & & & & & & & & & & & & & Help & Sup. \\
\hline 1 & 40 & 38 & 1 & 0 & 0 & 0 & - & - & - & - & - & - & - & N.D.* & N.D. \\
\hline 2 & 56 & 32 & 0 & 6 & 3 & 13 & 53 & 55 & 0 & 0 & 0 & - & 0 & - & + \\
\hline 3 & 33 & 50 & 1 & 3 & 25 & 1 & 49 & 45 & 0 & 0 & 3 & 0 & 0 & - & + \\
\hline 4 & 8 & 76 & 0 & 2 & 21 & 2 & 79 & 75 & 0 & 0 & 31 & 2 & 0 & - & + \\
\hline 5 & 62 & 88 & 0 & 1 & 63 & 52 & 91 & 90 & 1 & & 3 & 7 & 0 & - & + \\
\hline 6 & 30 & 89 & 1 & 1 & 36 & 74 & 89 & 1 & 0 & 0 & 2 & - & - & N.D. & N.D. \\
\hline 7 & 24 & 23 & 0 & 0 & 2 & 8 & 20 & 12 & 21 & 0 & 40 & - & - & - & - \\
\hline 8 & 58 & 55 & 0 & 0 & 0 & 0 & 0 & 1 & - & - & 0 & 4 & 0 & - & - \\
\hline 9 & 37 & 86 & 2 & 2 & 2 & 5 & 84 & 83 & 0 & 0 & 0 & 70 & 2 & - & + \\
\hline 10 & 70 & 82 & 0 & 1 & 0 & 0 & 18 & 19 & - & - & 11 & 5 & 1 & - & + \\
\hline 11 & 82 & 76 & 7 & 12 & 7 & 30 & 89 & 58 & - & - & 10 & 4 & 0 & - & - \\
\hline
\end{tabular}

* N.D., not done. 


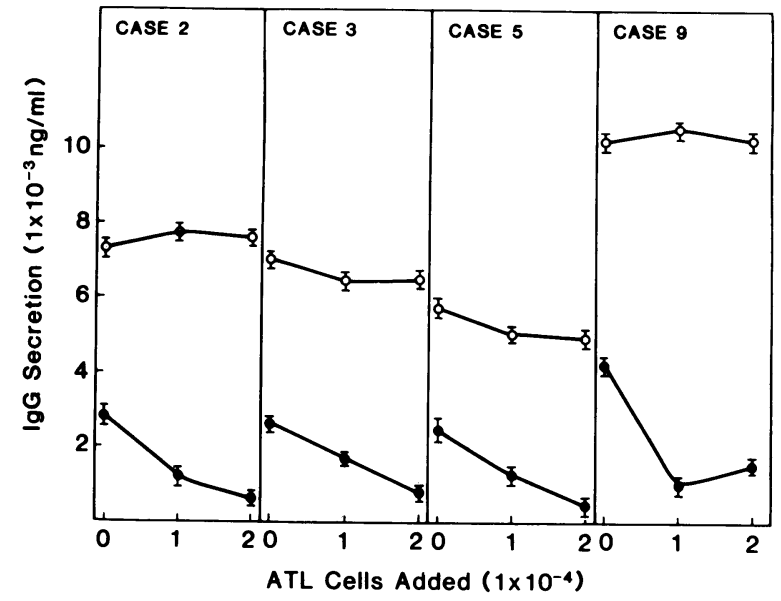

Figure 3. Cellular basis of suppression of PWM stimulated IgG synthesis by Japanese ATL cells. Varying numbers of ATL cells were added to a mixture of B cells $\left(5 \times 10^{4}\right)$ and T4 cells $\left(2 \times 10^{4}\right)$ in the absence $(-\circ-)$ or presence $(-\bullet-)$ of T8 cells $\left(1 \times 10^{4}\right)$. The mixture was stimulated with PWM for $7 \mathrm{~d}$ and IgG synthesis was assayed in a solid phase RIA. Results are mean of triplicate samples. SE was $<10 \%$.

As shown in Table III, when normal donors' PBLs were assayed for NK activity, significant lysis was observed. For comparison, JT9, a known NK-specific clone, is compared and it is evident that even at a low effector/target ratio, significant killing is seen. In contrast, all five ATL patients tested had no NK activity with or without prior culture. Moreover, the lack of NK activity is consistent with the absence of 901 antigen expression on ATL cells. It is, therefore, unlikely that the suppression of IgG production was mediated by NK activity of ATL cells. Nevertheless, it should be noted that patients with ATL are profoundly deficient in NK activity.

\section{Discussion}

In this study, we have characterized the cell surface phenotype and immunoregulatory function of Japanese ATL cells. Although all ATL cells tested were T4 positive, considerable

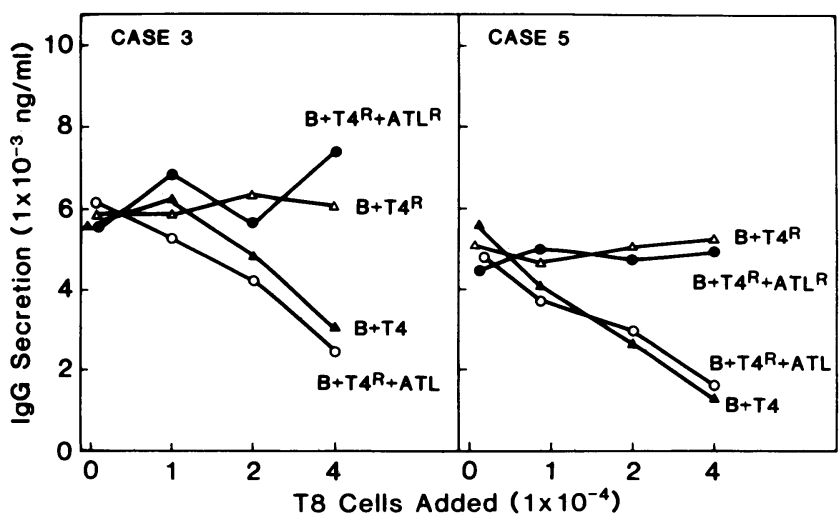

Figure 4. Irradiated ATL cells cannot mediate suppressor inducer function. To a mixture of B cells containing either irradiated or nonirradiated T4 or ATL cells in the presence of PWM, varying numbers of fresh normal $\mathrm{T} 8$ cells were added. IgG production was assayed by RIA using the 7-d culture supernatant. Results are mean of triplicate samples. SE was $<10 \%$.
Table III. NK Activity of ATL Cells

\begin{tabular}{lllll}
\hline & \multicolumn{4}{l}{ Effector/target ratio } \\
\cline { 2 - 5 } Cell source & 60 & 30 & 15 & 7.5 \\
\hline Healthy donors (3) & $40^{*}$ & 22 & 15 & 10 \\
Human NK clone (JT9) & ND§ & ND & 90 & 70 \\
ATL patients & & & & \\
Case 3 & 2 & 0 & 0 & 0 \\
$\quad 4 \ddagger$ & 1 & 0 & 0 & 0 \\
5 & 0 & 0 & 0 & 0 \\
$9 \ddagger$ & 3 & 0 & 0 & 0 \\
$10 \ddagger$ & 1 & 0 & 0 & 0
\end{tabular}

* Percent specific cytotoxicity, SD $<5 \%$.

Target cells used J.M. T cell lines.

¥ ATL cells were cultured with PWM for $7 \mathrm{~d}$ and then NK activity was assayed.

$\S \mathrm{ND}$, not done.

phenotypic heterogeneity was noted when these cells were analyzed with a series of anti-T cell antibodies. Functionally, these ATL cells seemed to be confined to the suppressor inducer subset of cells since they required T8+ cells to effect maximum suppression.

The phenotypic analysis of Japanese ATL cells by a series of 13 monoclonal antibodies showed that all ATL cells have mature T4+ inducer phenotype. However, some ATL cells had different reactivity with T3, T11, and T12 monoclonal antibodies. The initial report by Hattori et al. (17) showed that all three ATL cells tested were $\mathrm{T} 4+$ and reacted equally with $\mathrm{T} 1$ and $\mathrm{T} 3$ monoclonal antibodies. Subsequent studies by Shimoyama et al. (19) reported that although ATL cells were largely T4 positive, some lacked the T4 antigen whereas others lacked T3. Thus, significant heterogeneity has been noted in the past. More recently, analysis of ATL cells from the Caribbean patients showed that these patients varied in their expressin of $\mathrm{T} 3$, but seemed more homogeneous with respect to their phenotype $\mathrm{T} 1+\mathrm{T} 4+\mathrm{T} 8-\mathrm{T} 11+(39)$. Note that only one of seven patients with ATL cells had cells that were strongly Tac positive, which was in contrast to the observations of other investigators $(17,40)$. One possible explanation is that we exclusively studied freshly separated ATL cells. Those cells, which were cryopreserved, had also been frozen immediately after separation from peripheral blood. More recently, Sugamura et al. (41) reported that Tac antigen of freshly separated PBL from five ATL patients was very weakly positive or undetectable by FACS analysis. The basis for this phenotypic heterogeneity is still ill-defined and may represent either anomalous expression of antigens secondary to malignant transformation or alternatively clonal malignant expansion of a minor subset of cells bearing this unusual phenotype. Comparable phenotypic heterogeneity has been defined for cloned lines of interleukin 2 (IL-2) dependent T cells with NK activity from peripheral blood with respect to their expression of some $\mathrm{T}$ cell antigens but not others $(35,36)$. These cloned lines have variable expression of a number of antigens including T3, $\mathrm{T} 11$, and $\mathrm{T} 12$, and are distinct from antigen triggered IL-2 dependent $T$ cell lines (36). Whether these clones of $T$ lymphocytes are representative of minor populations of cells present in low frequency in human peripheral blood or result from the cloning procedures has not been resolved. To help 
resolve this matter, minor subsets of normal $\mathrm{T}$ cells bearing unusual phenotypes corresponding to some ATL cells will need to be identified and functionally characterized.

Previously, it was reported that ATL cells lacked helper activity and in some cases were suppressive in an allogeneic PWM-induced B cell immunoglobulin synthesis system (12, 17, 18). In the present studies, we also found that ATL cells were suppressive when added to PWM driven system. The mechanism of suppression, however, seems to be more complex than originally thought. The present studies suggest that ATL cells function mainly as inducers of suppressor cells, which can activate normal T8+ precursors of suppressor cells into suppressor effectors. ATL cells have little effect on mixtures of T4 and B cells in the absence of T8 cells. Some investigators indicated that ATL cells could directly function as effectors of suppression $(39,42)$. The discrepancy between those results and our own is not entirely clear. One possibility is that ATL cells express IL-2 receptors that can bind IL-2 present in the media, which can result in suppression of $T$ cell dependent immunoglobulin synthesis. In other studies $(39,40,42)$, they needed higher proportions of leukemic cells and higher ratios of leukemic cells to B cells for suppression of PWM-induced Ig synthesis, which is in contrast to our assay system, in which we used a low number of leukemic cells and a low leukemic cell to B cell ratio. In this regard, it has been shown that antigen specific helper $T$ cell clones provide optimal help at low numbers of T4+ cells, but at larger numbers of T4 clones they can inhibit specific antibody production (43). Alternatively, it is well known that B cell preparations can vary in their purity and variable numbers of contaminating $T$ cells (44). Thus, the addition of ATL cells to a mixture of "pure-B" and T4 cells could lead to the suppression secondary to the small numbers of $\mathrm{T} 8$ cells contaminating the $\mathrm{B}$ cell preparation.

Recent studies from our laboratory have demonstrated Epstein-Barr virus transformed autologous B cell lines could induce three discrete regulatory $T$ cell clones: $T 4+$ helper, T4+ inducer of suppressor, and T8 suppressor effector (34). These observations supported earlier studies demonstrating that the T4+ subset could be divided into two functionally distinct subpopulations on the basis of their reactivity with JRA autoantibodies and radiosensitivity $(8,9,11)$. The T4+JRA+ population was shown to express suppressor inducer function analogous to some ATL cells described above. The T4+JRA - subset, in contrast, accounted for a fraction of the T4 population and provided help. Thus, the majority of ATL cells we have tested to date seem to be leukemic counterparts of the T4+ suppressor inducer subset. In contrast, most Sezary cells so far reported with helper functions $(20,45)$ seem to correspond to the T4+ helper-inducer subset. These distinct subsets of $\mathrm{T} 4$ cells have now been well defined in human systems with the Leu reagents $(46,47)$ as well as in murine systems with the Ly reagents $(48,49)$. Why the presumed etiologic agent HTLV has a predilection for this subset of $T$ cells in vivo and not another is presently unclear but at the very least suggests the presence of a virus receptor allowing infectivity and clonal expansion.

The decreased NK activity of ATL cells is also of interest. Whether this decrease in NK activity is a secondary phenomenon relevant to the leukemic process or an expression of diminished host surveillance against HTLV virus transformed cells is not clear. In this regard, it has been suggested that the accelerated lymphoma-like phase of the Chediak-Higashi syndrome results from the demonstrated dysfunction of NK cells $(50,51)$. Further studies will be required to clarify whether the high incidence of ATL in patients born in the southern area of Kyushu in Japan or in the Caribbean have a more central defect in NK activity. Lastly, the present studies support the notion that a more complete understanding of normal human immunoregulatory $T$ cell function will result from a careful investigation of $\mathrm{T}$ cell leukemias.

\section{Acknowledgments}

The authors thank Professor M. Tashiro, Department of Dermatology, Kagashima University School of Medicine for providing patients' cells. We would also like to thank Ms. Judy A. Distaso and Mr. David Leslie for their skillful technical assistance. Finally, we would like to thank Ms. Diana Sam for her excellent secretarial assistance during the preparation of this manuscript.

This work was supported by National Institutes of Health grants AI 12069 and CA 19589.

\section{References}

1. Reinherz, E. L., and S. F. Schlossman. 1980. Regulation of the immune response: inducer and suppressor $T$ lymphocyte subsets in man. N. Engl. J. Med. 303:370-373.

2. Germain, R. N., and B. Benacerraf. 1980. Helper and suppressor factors. Springer Semin. Immunopathol. 3:93-127.

3. Reinherz, E. L., P. C. Kung, G. Goldstein, and S. F. Schlossman. 1979. Separation of functional subsets of human $T$ cells by a monoclonal antibody. Proc. Natl. Acad. Sci. USA. 76:4061-4065.

4. Reinherz, E. L., P. C. Kung, G. Goldstein, and S. F. Schlossman. 1980. A monoclonal antibody reactive with the human cytotoxic/ suppressor $\mathrm{T}$ cell subset previously defined by heteroantiserum termed $\mathrm{TH}_{2}$. J. Immunol. 124:1301-1307.

5. Ledbetter, J., R. L. Evans, M. Lipinski, C. CunninghamRundels, R. R. Good, and L. A. Herzenberg. 1981. Evolutionary conservation of surface molecules that distinguish $\mathrm{T}$ lymphocyte inducer and cytotoxic/suppressor subpopulations in mouse and man. J. Exp. Med. 153:310-320.

6. Uchiyama, T., S. Broder, and T. A. Waldmann. 1981. A monoclonal antibody (anti-Tac) reactive with activated and functionally mature human T cells. I. Production of anti-Tac monoclonal antibody and distribution of Tac+ cells. J. Immunol. 126:1393-1397.

7. Thomas, Y., J. Sosman, O. Irigoyen, S. J. Friedman, P. C. Kung, G. Goldstein, and L. Chess. 1980. Functional analysis of human $\mathrm{T}$ cell subsets defined by monoclonal antibodies. I. Collaborative T-T interactions in the immunoregulation of B cell differentiation. $J$. Immunol. 125:2402-2408.

8. Morimoto, C., E. L. Reinherz, Y. Borel, E. Mantzouranis, A. D. Steinberg, and S. F. Schlossman. 1981. Autoantibody to an immunoregulatory inducer population in patients with juvenile rheumatoid arthritis. J. Clin. Invest. 67:753-761.

9. Morimoto, C., J. Distaso, Y. Borel, S. F. Schlossman, and E. L. Reinherz. 1982. Communicative interactions between subpopulations of human $\mathrm{T}$ lymphocytes required for generation of suppressor effector function in a primary antibody response. J. Immunol. 128:1645-1650.

10. Gatenby, P. A., B. L. Kotzin, G. S. Kansas, and E. G. Engelman. 1982. Immunoglobulin secretion in the human autologous mixed leukocyte reaction. Definition of a suppressor amplifier circuit using monoclonal antibodies. J. Exp. Med. 156:55-67.

11. Morimoto, C., E. L. Reinherz, Y. Borel, and S. F. Schlossman. 1983. Direct demonstration of the human suppressor inducer subset by anti-T cell antibodies. J. Immunol. 130:157-161. 
12. Uchiyama, T., J. Yodoi, K. Sagawa, K. Takatuki, and H. Uchino. 1977. Adult T cell leukemia: clinical and hematological features of 16 cases. Blood. 50:481-492.

13. Takatsuki, K., T. Uchiyama, T. Ueshima, T. Hattori, T. Toibana, M. Tsudo, Y. Wano, and J. Yodoi. 1982. Adult T cell leukemia: proposal as a new disease and cytogenetic, phenotypic and functional studies of leukemic cells. Gann Monogr. Cancer Res. 28: 13-22.

14. Poiesz, B. J., F. W. Fuscetti, A. F. Gazder, P. A. Bunn, J. D. Minna, and R. C. Gallo. 1980. Detection and isolation of type-C retrovirus particles from fresh and cultured lymphocytes of a patient with cutaneous T cell lymphoma. Proc. Natl. Acad. Sci. USA. 77: 7415-7419.

15. Gallo, R. C., D. Mann, S. Broder, F. W. Ruscetti, M. Maeda, V. S. Kalyanaraman, M. Robert-Guroff, and M. S. Reitz, Jr. 1982. Human T-cell leukemia-lymphoma virus (HTLV) is in T- but not Blymphocytes from a patient with cutaneous $\mathrm{T}$ cell lymphoma. Proc. Natl. Acad. Sci. USA. 79:5680-5683.

16. Hinuma, Y., K. Nagata, M. Hanaoka, M. Nakai, T. Matsumoto, K. Kinoshita, S. Shirakawa, and I. Miyoshi. 1981. Adult T-cell leukemia: antigen in an ATL cell line and detection of antibodies to the antigen in human sera. Proc. Natl. Acad. Sci. USA. 78:6476-6480.

17. Hattori, T., T. Uchiyama, T. Toibana, K. Takatsuki, and H. Uchino. 1981. Surface phenotype of Japanese adult T-cell leukemia cells characterized by monoclonal antibodies. Blood. 58:645-647.

18. Uchiyama, T., K. Sagawa, K. Takatsuki, and H. Uchino. 1978. Effect of adult T-cell leukemia cells or pokeweed mitogen-induced normal B cell differentiation. Clin. Immunol. Immunopathol. 10:2434.

19. Shimoyama, M., K. Tobinai, M. Hirose, and K. Minato. 1982. Cellular origin of T cell malignancies. Gann Monogr. Cancer Res. 28: 23-25.

20. Broder, S., R. L. Edelson, M. A. Lutzner, D. L. Nelson, R. P. MacDermott, M. E. Durm, C. K. Goldman, B. D. Meade, and T. A. Waldman. 1976. The Sezary syndrome. A malignant proliferation of helper T cells. J. Clin. Invest. 58:1297-1306.

21. Haynes, B. P., R. S. Metzgar, J. D. Minna, and P. A. Bunn. 1981. Phenotypic characterization of cutaneous T cell lymphoma: use of monoclonal antibodies to compare with other malignant T cells. $N$. Engl. J. Med. 304:1314-1323.

22. Morimoto, C., R. F. Todd, J. A. Distaso, and S. F. Schlossman. 1981. The role of the macrophage in in vitro primary anti-DNP antibody production in man. J. Immunol. 127:1137-1141.

23. Reinherz, E. L., P. C. Kung, G. Goldstein, and S. F. Schlossman. 1979. A monoclonal antibody with selective reactivity with functionally mature human thymocytes and all peripheral human $\mathrm{T}$ cells. $J$. Immunol. 123:1312-1317.

24. Todd, R. F., L. M. Nadler, and S. F. Schlossman. 1981. Antigens on human monocytes identified by monoclonal antibodies. J. Immunol. 126:1435-1442.

25. Reinherz, E. L., P. C. Kung, G. Goldstein, R. Levey, and S. F. Schlossmann. 1980. Discrete stages of human intrathymic differentiation: analysis of normal thymocyte and leukemic lymphoblasts of $T$ lineage. Proc. Natl. Acad. Sci. USA. 77:1588-1592.

26. Howard, F. D., J. A. Ledbetter, J. Wong, C. P. Bieber, E. B. Stitson, and L. A. Herzenberg. 1981. A human T lymphocyte differentiation marker that blocks rosette formation. J. Immunol. 126:21172122.

27. Reinherz, E. L., S. C. Meuer, K. A. Fitzgerald, R. E. Hussey, H. Levine, and S. F. Schlossman. 1982. Antigen recognition by human $T$ lymphocytes is linked to surface expression of the T3 molecular complex. Cell. 30:735-743.

28. Nadler, L. M., J. Ritz, R. Hardy, J. M. Pesando, and S. F. Schlossman. 1981. A unique cell surface antigen identifying lymphoid malignancies of B cell origin. J. Clin. Invest. 67:134-140.
29. Ritz, J., J. M. Pesando, J. Notis-McConarty, H. Lazarus, and S. F. Schlossman. 1980. A monoclonal antibody to acute lymphoblastic leukemic antigen. Nature (Lond.). 283:583-585.

30. Nadler, L. M., P. Stashenko, R. Hardy, J. M. Pesando, E. J. Yunis, and S. F. Schlossman. 1981. Monoclonal antibodies defining serologically distinct HLA-D/DR related la-like antigen in man. Hum. Immunol. 1:77-90.

31. Leonard, W. J., J. M. Depper, T. Uchiyama, K. A. Smith, T. A. Waldman, and W. C. Greene. 1982. A monoclonal antibody that appears to recognize the receptor for human $\mathrm{T}$ cell growth factor: Partial characterization of the receptor. Nature (Lond.). 300:262-264.

32. Griffin, J. D., T. Hercend, R. Beveridge, and S. F. Schlossman. 1983. Characterization of an antigen expressed by human natural killer cells. J. Immunol. 130:2947-2951.

33. Morimoto, C., E. L. Reinherz, S. F. Schlossman, P. H. Schur, J. A. Mills, and A. D. Steinberg. 1982. Alterations in immunoregulatory $\mathrm{T}$ cell subsets in active systemic lupus erythematosus. J. Clin. Invest. 66:1171-1174

34. Meuer, S. C., D. A. Cooper, J. C. Hodgdon, R. E. Hussey, C. Morimoto, S. F. Schlossman, and E. L. Reinherz. 1983. Immunoregulatory human $\mathrm{T}$ lymphocytes triggered as a consequence of viral infection: clonal analysis of helper, suppressor inducer and suppressor effector cell populations. J. Immunol. 131:1167-1172.

35. Hercend, T., S. C. Meuer, E. L. Reinherz, S. F. Schlossman, and J. Ritz. 1982. Generation of a cloned NK cell line derived from the "null cell" fraction of human peripheral blood. J. Immunol. 129: 1299-1305.

36. Hercend, T., E. L. Reinherz, S. C. Meuer, S. F. Schlossman, and J. Ritz. 1983. Phenotypic and functional heterogeneity of human cloned natural killer cell lines. Nature (Lond.). 301:158-160.

37. Lando, Z., P. Sarin, M. Megson, W. C. Greene, T. A. Waldman, R. C. Gallo, and S. Broder. 1983. Association of human T cell leukaemia/lymphoma virus with the Tac antigen marker for the human T cell growth factor receptor. Nature (Lond.) 305:733-736.

38. Rimm, I. J., S. F. Schlossman, and E. L. Reinherz. 1981. Antibody-dependent cellular cytotoxicity and natural killer-like activity are mediated by subsets of activated T cells. Clin. Immunol. Immunopathol. 21:134-140.

39. Miedema, F., F. G. Terpstra, J. W. Smit, S. Daenen, W. Gerrits, V. Hedge, E. Matutes, D. Catovsky, M. F. Greaves, and C. J. M. Melief. 1984. Functional properties of neoplastic T cells in adult $\mathrm{T}$ cell lymphoma/leukemia patients from the Caribbean. Blood. 63:477-481.

40. Waldman, T. A., W. C. Greene, P. S. Sarin, C. Saxinger, D. W. Blayney, W. A. Blattner, C. K. Goldman, K. Bongiovanni, S. Sharrow, J. M. Depper, W. Leonard, T. Uchiyama, and R. C. Gallo. 1984. Functional and phenotypic comparison of human $\mathrm{T}$ cell leukemia/ lymphoma virus positive adult $T$ cell leukemia with human $T$ cell leukemia/lymphoma virus negative Sezary leukemia, and then distinction using anti-Tac. J. Clin. Invest. 73:1711-1718.

41. Sugamura, K., M. Fuji, M. Kannagi, M. Sakitani, M. Takeuchi, and Y. Hinuma. 1984. Cell surface phenotypes and expression of viral antigens of various human cell lines carrying human T-cell leukemia virus. Int. J. Cancer. 34:221-228.

42. Yamada, Y. 1983. Phenotypic and functional analysis of leukemic cells from 16 patients with adult $T$ cell leukemia/lymphoma. Blood. 61:192-199.

43. Lamb, J. R., J. N. Woody, R. J. Hartzman, and D. D. Eckels. 1982. In vitro influenza virus-specific antibody production in man: antigen-specific and HLA-restricted induction of helper activity mediated by cloned human T lymphocytes. J. Immunol. 129:1465-1470.

44. Anderson, K. C., J. D. Griffin, M. P. Bates, B. L. Slaughenhoupt, S. F. Schlossman, and L. M. Nadler. 1983. Isolation and characterization of human B lymphocyte enriched populations. I. Purification of B cells by immune rosette depletion. J. Immunol. Methods. 61:283-292. 
45. Haynes, B. F., P. Bunn, D. Mann, C. Thomas, G. S. Eisenbarth, J. Minna, and A. S. Fauci. 1981. Cell-surface differentiation antigens of the malignant $T$ cell in Sezary syndrome and mycosis fungoides. $J$. Clin. Invest. 67:523-530.

46. Gatenby, P. A., G. S. Kansas, C. Y. Xian, R. L. Evans, and E. G. Engleman. 1982. Dissection of immunoregulatory subpopulations of $T$ lymphocytes within the helper and suppressor sublineages in man. J. Immunol. 129:1997-2000.

47. Damle, N. K., N. Mohagheghpour, and E. G. Engleman. 1984. Soluble mitogen-primed inducer $\mathrm{T}$ cells activate antigen-specific suppressor $T$ cells in the absence of antigen-pulsed accessory cells: phenotypic definition of suppressor-inducer and suppressor-effector cells. J. Immunol. 132:644-650.

48. Eardley, D. D., J. Hugenberger, L. McVay-Boudreau, F. W. Shen, R. K. Gershon, and H. Cantor. 1978. Immunoregulatory circuits among $T$ cell sets. $I$. T-helper cell induce other $T$ cell sets to exert feedback inhibition. J. Exp. Med. 147:1106-1115.

49. Cantor, H., J. Hugenberger, L. McVay-Boudreau, D. D. Eardley, J. Kemp, F. W. Shen, and R. K. Gershon. 1978. Immunoregulatory circuits among $\mathrm{T}$ cell sets. Identification of a subpopulation of $T$ helper cells that induces feedback inhibition. J. Exp. Med. 148:871877.

50. Roder, J. C., T. Haliotis, M. Klein, S. Korec, J. R. Jett, J. Ortaldo, R. B. Heberman, P. Katz, and A. S. Fauci. 1980. A new immunodeficiency disorder in humans involving NK cells. Nature (Lond.). 284:553-555.

51. Merino, F., G. O. Klein, W. Henle, P. Ramirez-duque, M. Forsgren, and C. Amesty. 1983. Elevated antibody titers to EpsteinBarr Virus and low natural killer cell activity in patients with ChediakHigashi syndrome. Clin. Immunol. Immunopathol. 27:326-339. 